\title{
Screening and Characterization of Rhizospheric Chitinolytic Bacteria for Evaluation of Their Potential as Biocontrol Agent against Phytopathogenic Fungi
}

\author{
Abhilipsa Parhi and Sukantibala Mohapatra* \\ Department of Microbiology, C.B.S.H., Orissa University of Agriculture and \\ Technology, Bhubaneswar, Odisha-751003, India \\ *Corresponding author
}

\begin{tabular}{|c|c|}
\hline & A B S T R A C T \\
\hline & \multirow{3}{*}{$\begin{array}{l}\text { The present study evaluated the antagonistic effect of the rhizospheric chitinolytic bacterial } \\
\text { isolates of rice and green gram soil samples against three phytopathogenic fungi, i.e. } \\
\text { Pythium aphanidermatum (ITCC No.-5488), Fusarium oxysporum (ITCC No.-4998) and } \\
\text { Rhizoctonia solani (ITCC No.-2060). A total of } 25 \text { bacterial isolates were obtained based } \\
\text { upon their distinct colony characteristics on colloidal chitin agar medium. Only } 6 \text { isolates } \\
\text { (G1, G2, R3, R4, R9 and R10) showed visible antagonistic activity against the test fungi } \\
\text { by dual culture method on potato dextrose agar (PDA) during primary screening. During } \\
\text { further screening by well diffusion method, all the } 6 \text { showed broad-spectrum antibacterial } \\
\text { activity by inhibiting most of the test fungal phytopathogens. The six effective isolates } \\
\text { were also able to reduce the fungal biomass of all the three test pathogens by mycelial } \\
\text { reduction test. Though R10 inhibited all the three fungal pathogens but maximum } \\
\text { reduction was observed against Rhizoctonia solani. Physiological \& biochemical } \\
\text { characterization of the effective isolates indicated that the antagonistic chitinolytic } \\
\text { bacterial belong to Bacillus sp. }\end{array}$} \\
\hline Article Info & \\
\hline & \\
\hline
\end{tabular}

\section{Introduction}

Plant diseases cause considerable losses in crop production and storage. Now-a-days growers still rely heavily on chemical pesticides to prevent or control these diseases, which can result in environmental contamination. The presence of pesticide residues on food also cause social and economic problem that heavily affects the economy of the country. Fungi (Fusarium sp., Rhizoctonia sp., Alternaria sp., Pythium sp. etc.) are parasitic pathogens which attack crop plants and are very dangerous. Fungal phytopathogens cause serious problems worldwide causing diseases like rusts, smuts, rots and wilt; which damages the crop (Goma et al., 2011). Biological control, using microorganisms to suppress plant disease offers powerful and alternative tool against the use of synthetic chemicals.

Chitinolytic bacteria such as Aeromonas hydrophila, Aeromonas caviae, Pseudomonas maltophilia, Bacillus licheniformis, Bacillus circulans, Vibrio furnissii, Xanthomonas sp. and Serratia marcescens have been reported as important biocontrol agents. Biological control using microorganism has been studied intensively, since not many alternatives to 
control plant diseases are available (Duffy et al., 1995).

Detection of chitin degrading bacteria from natural sources such as rhizosphere soil is useful in the isolation of bacteria that produce antifungal or other novel compounds. There is a higher correlation between chitinolytic and production of bioactive compounds (Hostel et al., 2005). Micro-organisms, which secrete a complex of mycolytic enzymes, are considered to be possible biological control agents of plant diseases against fungal pathogen (Helisto et al., 2001 and Chang et al., 2003). The objective of the present study is to isolate the native chitinolytic bacteria from the rhizosphere soil of rice and green gram as well as from the fish dump waste to study their potential in biocontrol of phytopathogenic fungi.

\section{Materials and Methods}

\section{Collection of sample}

Rice and green gram rhizospheric soil samples were collected from O.U.A.T farm separately by digging the soil $3-4 \mathrm{~cm}$ deep after removing the surface soil with the help of sterile spatula carefully from four different regions of each field and brought to the laboratory for microbiological analysis.

\section{Phytopathogens used}

The three phytopathogens i.e., Pythium aphanidermatum (ITCC No.-5488), Rhizoctonia solani (ITCC No.-2060), Fusarium oxysporum (ITCC No.-4998) were used in the present study.

\section{Preparation of colloidal chitin}

For colloidal chitin preparation, chitin (10g) was added to $170 \mathrm{~mL}$ of conc. $\mathrm{HCl}$ and kept under vigorous stirring for $2 \mathrm{~h}$ at room temperature until the chitin was dissolved completely. The above suspension was precipitated by slowly adding ice cold ethanol. The $\mathrm{pH}$ of the suspension was adjusted to 7.2 - 7.3 by adding $10 \mathrm{~N}$ sodium hydroxide. The above suspension was centrifuged at $8000 \mathrm{rpm}$ for $10 \mathrm{~min}$. The precipitate was collected and used as medium substrate (Faramarzi et al., 2009).

\section{Isolation of chitinolytic bacteria}

Isolation of the chitinolytic bacteria was done following tenfold serial dilution of the soil samples on LB agar medium under aerobic condition.

Then selective isolates was done on colloidal chitin agar medium, where chitin was the sole source of carbon and energy. Colonies showing zones of clearance against the creamy background were regarded as chitinase-producer and restreaked until pure cultures were obtained. The selected chitinolytic bacteria were considered for further studies (Kamil et al., 2007).

\section{In vitro antibiosis study of the bacterial} isolates against fungal phytopathogens

Only the 6 isolates showing the maximum zone of clearance in the colloidal agar medium were screened against the three fungal phytopathogens to study their antagonistic activity. The preliminary screening was done by dual culture method and the secondary screening test by well diffusion method and mycelial reduction test. All the tests were done by triplicate (Table 4).

\section{Dual culture method}

The fungal growth inhibition capacity of the isolates was determined by dual culture method (Balaz et al., 2000). From the fresh fungal culture plates, $6 \mathrm{~mm}$ diameter agar 
discs of each pathogen were placed at the centre of PDA plates. The chitinolytic bacterial isolates were streaked around the fungal agar discs in rectangular form. The plates were incubated for $72 \mathrm{~h}$ at $30^{\circ} \mathrm{C}$ and colony diameter of the fungal pathogens were measured and compared with the control (Fig. 2, Table 2).

\section{Well diffusion method}

Freshly prepared PDA plates were used to study the antifungal activity of the isolates against fungal phytopathogens.

Two wells were punched on the plates at an equal distance from the centre using a cork borer and $0.1 \mathrm{ml}$ of $24 \mathrm{~h}$ bacterial broth suspension of the isolates were added to the wells.

The punched test fungal pathogens i.e. $R$. solani, $F$. oxysporum, $P$. aphanidermatum from the revived plates were inoculated at the centre of the PDA plate, followed by incubation at $30^{\circ} \mathrm{C}$ for 5 days in order to study the antibiosis.

\section{Mycelial reduction test in liquid medium}

Mycelial reduction test was performed using Potato Dextrose broth (PDB). 20ml of the PDB were taken in screw capped vials. 4 agar discs of $6 \mathrm{~mm}$ diameter was punched out from fungal culture plate and dispensed in the fungus control vial.

Similarly 4 discs of fungal colony of $6 \mathrm{~mm}$ diameter were dispensed in the treatments $\left(\mathrm{T}_{1}\right.$ $\& \mathrm{~T}_{2}$ ). One loopful of fresh broth culture of chitinolytic bacteria was inoculated in the treatments simultaneously. All the tubes were incubated at $30^{\circ} \mathrm{C}$ for 3,5 and 7 days. After incubation, the fungal mycelia were harvested separately from each flask and dried to constant weight in an oven at $100^{\circ} \mathrm{C}$. The antagonistic effect of the isolates was checked by measuring the $\%$ of inhibition of the fungal mass following the formula (Reddy and Hynes, 1993).

$\%=$ Control-treatment $/$ control $\times 100$

\section{Morphological characterization}

All the bacterial isolates were examined for their cell morphology (cell shape, margin, and cell arrangement) by Gram's Stain technique.

\section{Physiological and biochemical characterization of the chitinolytic bacterial isolates}

Physiological and Biochemical characteristics of the antagonistic isolates were checked following the standard methods of identification.

Overnight culture of the purified isolates was used for the entire biochemical tests. All the test isolates were identified using ABIS online software (Table 5).

\section{Results and Discussion}

A total of 25 bacteria were selected based on different colony morphology. Out of 25, 10 isolates were found positive for chitinolytic activity using colloidal chitin agar (Table 1, Fig. 1).

Detection of chitin degrading bacteria from natural sources such as rhizosphere soil is useful in the isolation of bacteria that produce antifungal or other novel compounds. There is a higher co-relation between chitinolytic and production of bioactive compounds (Hostel et al., 2005).

Chitinase is known as one of the antifungal protein (Gohel et al., 2006). Chitinase produced by the isolates should be considered as enzyme responsible in lysing chitin polymer of the fungal hyphae (Shanmugaiah et al., 2008). 
Table.1 Effective chitinolytic bacterial on their zone of clearance on Colloidal chitin agar medium

\begin{tabular}{|c|c|}
\hline Isolates code & Zone of clearance (in mm) \\
\hline $\mathrm{G}_{1}$ & 72.0 \\
\hline $\mathrm{G}_{2}$ & 70.0 \\
\hline $\mathrm{G}_{6}$ & 65.0 \\
\hline $\mathrm{R}_{3}$ & 80.0 \\
\hline $\mathrm{R}_{4}$ & 87.0 \\
\hline $\mathrm{R}_{6}$ & 77.0 \\
\hline $\mathrm{R}_{7}$ & 65.0 \\
\hline $\mathrm{R}_{8}$ & 70.0 \\
\hline $\mathrm{R}_{9}$ & 72.5 \\
\hline $\mathrm{R}_{10}$ & 97.0 \\
\hline
\end{tabular}

Table.2 Antifungal activity of the bacterial isolates by dual culture method

\begin{tabular}{|l|l|l|l|l|l|l|l|l|l|l|l|l|}
\hline \multirow{2}{*}{$\begin{array}{l}\text { Isolates } \\
\text { Code }\end{array}$} & \multicolumn{9}{c|}{ Rone of inhibition (in mm) } \\
\cline { 2 - 17 } & \multicolumn{9}{|c|}{ solani } & \multicolumn{9}{c|}{ Fxysporum } & \multicolumn{3}{c|}{ P. aphanidermatum } \\
\hline Days & $\mathbf{1}$ & $\mathbf{2}$ & $\mathbf{3}$ & $\mathbf{4}$ & $\mathbf{1}$ & $\mathbf{2}$ & $\mathbf{3}$ & $\mathbf{4}$ & $\mathbf{1}$ & $\mathbf{2}$ & $\mathbf{3}$ & $\mathbf{4}$ \\
\hline Control & -- & 38 & 40 & 40 & -- & 21 & 28 & 28 & -- & 12 & 18 & 18 \\
\hline G1 & -- & 5 & 6 & 6 & -- & 7 & 8 & 8 & -- & 8 & 9 & 9 \\
\hline G2 & -- & 6 & 7 & 7 & -- & 9 & 9 & 9 & -- & 6 & 6.5 & 6.5 \\
\hline R3 & -- & 7 & 11 & 11 & -- & 6 & 8 & 8 & -- & 7 & 8 & 8 \\
\hline R4 & -- & 7 & 12 & 12 & -- & 7 & 9 & 9 & -- & 6 & 6 & 6 \\
\hline R9 & -- & 8 & 11 & 11 & -- & 8 & 8 & 8 & -- & 7 & 8 & 8 \\
\hline R10 & -- & 9 & 11 & 11 & -- & 10 & 11 & 11 & -- & 9 & 9.5 & 9.5 \\
\hline
\end{tabular}

--: No growth, G: Green gram soil, R: Rice field soil

Table.3 Anti-fungal activity (growth inhibition) of the bacterial isolates by well diffusion method

\begin{tabular}{|c|c|c|c|}
\hline \multirow{2}{*}{$\begin{array}{c}\text { Bacterial } \\
\text { Isolates }\end{array}$} & \multicolumn{3}{|c|}{ Zone of inhibition (in mm) } \\
\cline { 2 - 4 } & $\boldsymbol{R}$. solani & F.oxysporum & P. aphanidermatum \\
\hline $\mathbf{G}_{\mathbf{1}}$ & 14.0 & -- & -- \\
\hline $\mathbf{G}_{\mathbf{2}}$ & -- & 8.0 & 8.0 \\
\hline $\mathbf{R}_{\mathbf{3}}$ & 6.0 & -- & -- \\
\hline $\mathbf{R}_{\mathbf{4}}$ & 6.0 & -- & -- \\
\hline $\mathbf{R}_{\mathbf{9}}$ & -- & 9.0 & -- \\
\hline $\mathbf{R}_{\mathbf{1 0}}$ & 18.0 & 6.0 & 6.0 \\
\hline
\end{tabular}

+: Inhibition, --: No growth 
Table.4 Secondary screening of the bacterial isolates by mycelial reduction test

\begin{tabular}{|c|c|c|c|c|c|c|c|c|c|}
\hline \multirow{3}{*}{ Bacteria } & \multicolumn{9}{|c|}{ \% of reduction } \\
\cline { 2 - 10 } & \multicolumn{3}{|c|}{$\boldsymbol{F}$ oxysporoum } & \multicolumn{3}{c|}{ R. solani } & \multicolumn{3}{c|}{ P. aphanidermatum } \\
\cline { 2 - 10 } & \multicolumn{3}{|c|}{ Days } & \multicolumn{3}{|c|}{ Days } & \multicolumn{3}{c|}{ Days } \\
\cline { 2 - 10 } & $\mathbf{3}$ & $\mathbf{5}$ & $\mathbf{7}$ & $\mathbf{3}$ & $\mathbf{5}$ & $\mathbf{7}$ & $\mathbf{3}$ & $\mathbf{5}$ & $\mathbf{7}$ \\
\hline $\mathbf{G}_{\mathbf{1}}$ & 50 & 60 & 60 & 40 & 50 & 50 & 56 & 60 & 60 \\
\hline $\mathbf{G}_{\mathbf{2}}$ & 60 & 65 & 65 & 55 & 60 & 60 & 50 & 55 & 55 \\
\hline $\mathbf{R}_{\mathbf{3}}$ & 45 & 54 & 54 & 50 & 50 & 50 & 60 & 65 & 65 \\
\hline $\mathbf{R}_{\mathbf{4}}$ & 55 & 60 & 60 & 60 & 62 & 62 & 65 & 70 & 70 \\
\hline $\mathbf{R}_{\mathbf{9}}$ & 58 & 60 & 60 & 45 & 52 & 52 & 54 & 58 & 58 \\
\hline $\mathbf{R}_{\mathbf{1 0}}$ & 64 & 70 & 70 & 60 & 78 & 78 & 55 & 67 & 67 \\
\hline
\end{tabular}

Table.5 Biochemical characterization of the effective chitinolytic bacterial isolates

\begin{tabular}{|l|c|c|c|c|c|c|c|c|c|c|c|c|}
\hline Strains & In & MR & VP & Ci & NR & Es & Ur & Mo & TSI & Amy & Gel & Oxd \\
\hline G1 & - & + & - & + & + & + & + & + & - & + & + & + \\
\hline G2 & - & + & - & + & - & + & + & + & + & + & + & + \\
\hline R3 & - & - & - & + & + & - & + & + & + & + & + & + \\
\hline R4 & - & + & - & + & - & - & + & + & + & + & + & + \\
\hline R9 & + & - & - & + & + & - & + & + & + & + & + & + \\
\hline R10 & - & + & - & + & + & - & + & + & + & + & + & + \\
\hline
\end{tabular}

In: Indole test; MR: Methyl red test; VP: Voges Proskauer test; Ci: Citrate utilization; NR: Nitrate reductase; Ur: Urease test; Es: Esculin hydrolysis; Mo: Motility test; TSI: Triple sugar iron test; Amy: Amylase test; Gel: Gelatinase test; Oxd: Oxidase test; +: Positive; - : Negative

Table.6 Test for different sugar utilization by the chitinolytic bacterial isolates

\begin{tabular}{|l|c|c|c|c|c|c|}
\hline Strains & Galactose & Lactose & Dextrose & Fructose & Maltose & Sucrose \\
\hline G1 & + & - & + & + & + & + \\
\hline G2 & + & + & + & + & + & - \\
\hline R3 & + & + & + & + & - & - \\
\hline R4 & + & + & + & + & + & + \\
\hline R9 & - & - & + & + & - & - \\
\hline R10 & - & - & + & + & + & + \\
\hline
\end{tabular}

Fig.1 Chitinolytic bacterial isolates on chitin agar medium by spread plate method at Different dilution

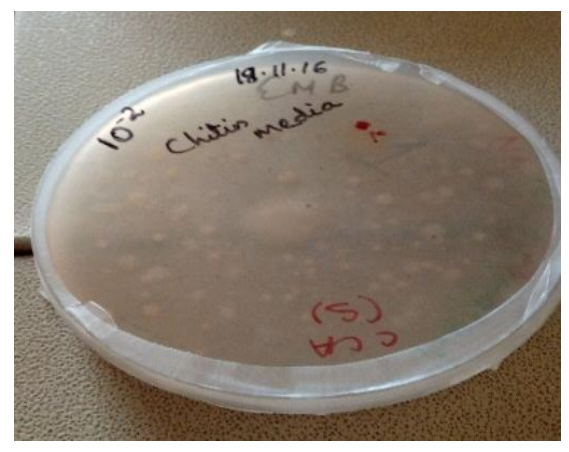


Fig.2 Screening of the bacterial isolates by dual culture method

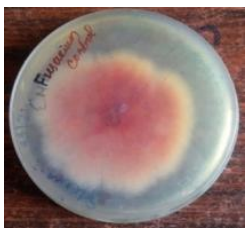

A. F.oxysporum (Control \& $\left.\mathrm{R}_{4}\right)$

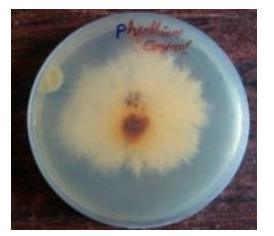

B. $P$. aphanidermatum (Control \& G1)

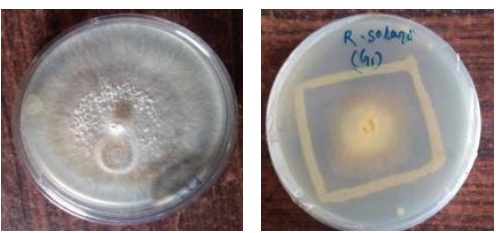

C. R. solani (Control \& $\left.\mathrm{G}_{1}\right)$
In this study, the ability of the selected chitinolytic strains in suppression of mycelial growth of phytopathogenic fungi was conducted. Following ABIS online software, the isolates were identified as Bacillus sp. Bacillus strains have been intensively investigated as biological control agents (Kamil et al., 2007) previously. They all have reported that members of the genus Bacillus are well known for their potential to secrete a member of degradative enzymes such as chitinase (Zhang and Zuen et al., 2000; Zhang et al., 2001; Schallmey et al., 2004).

To test the ability of the selected chitinolytic isolates in suppression of mycelial growth of phytopathogenic fungi including Rhizoctonia solani in vitro, antifungal assay was performed. It was found that all the 6 chitinolytic isolates antagonized the tested phytopathogen but to a varying degree (Table $3)$.

All were inhibiting $R$. solani having different inhibition zone size. They have reported a modification of the fungal mycelium appearance due to antifungal secondary metabolite production. Our results are in agreement with those obtained by (Sid Ahmed et al., 2003), who reported that chitinolytic bacteria were active against the fungal pathogens of pepper, sorghum and mango. Protection of plants from disease produced by phytopathogenic fungi is one of the most important challenges in agriculture. Therefore, finding a biological agent that could be used for biocontrol of fungal diseases is very much important in agriculture. The study showed that soil from rhizosphere is the best source for chitinolytic bacteria.

\section{Acknowledgement}

The authors are thankful to Dr. B.B. Mishra, HOD, Microbiology Department, O.U.A.T for providing laboratory facilities during the period of study. The authors have no conflict of interst to declare.

\section{References}

Balaž, J., Stojšin, V., and Bagi, F., 2000. Mogućnost suzbijanja truleži plodova jabuke (Monilinia spp.) antagonistima iz roda Trichoderma. Eko-konferencija, Ekološki pokret grada Novog Sada, Pp. 43-48.

Chang, W.T., Chen YC, Jao CL. 2007. Antifungal activity and enhancement of plant growth by Bacillus cereus grown on shellfish chitin wastes. Bioresour Technol. 98 Suppl6:1224-30.

De Boer, W., Gerards S, Klein Gunnewiek PJA and Modderman R 1999. Response of the chitinolytic microbial community to chitin amendments of dune soils. Biology and Fertility of soils 29:170177.

Duffy, et al.,1995 BK Duffy,S Andrew,DM Weller Combination of Trichoderma coningii with fluorescent Pseudomonads for control of take all on wheat. Phytopathology, 93(2003): 626632. 
Faramarzi, M.A., Fazeli, M., Yazdi, M.T., Adrangi, S., AI-Ahmadi, K.J., Tasharrofi, N. and Mohseni, F.A.2009.optimization of cultural condition for production chitinase by soil isolate of Massilia timonae. Biotechnology, 8; 93-99.

Gohel, V., Singh A, Vimal M, Ashwini P, Chhatpar HS. 2006. Bioprospecting and antifungal potential of chitinolytic microorganisms. Afr J Biotechnol, 5(2):54.

Helisto, P., G. Aktuganov, N. Galimzianova, A. Melentjev and T. Korpela, 2001. Lytic enzyme complex of an antagonistic Bacillus sp. X-b. Isolation and purification of components. J. Chromatography, B 758: 197-205.

Hoster, F., J.E. Schmitz and R. Daniel. 2005. Enrichment of chitinolytic microorganisms: Isolation and characterization of a chitinase exhibiting antifungal activity against phytopathogenic fungi from a novel Streptomyces strain. Appl. Microbiol. Biotechnology, 66: 434-442.

Kamil, Z., Rizk, M., Saleh, M., and Moustafa, S. 2007. Isolation and identification of rhizosphere soil chitinolytic bacteria and their potential in antifungal biocontrol. Global J. Mol. Sci, 2: 57-66.

Reddy, M.C., and Hynes, R. K. 1993. Relationship between in vitro growth inhibition of pathogens and suppression of pre-emergence damping-off and post emergence root rot of white bean seedlings in the green house by bacteria. Can J. Microbiol. 40: 113-119.

Schallmey, M., A. Singh and O.P. Ward, 2004. Developments in the use of Bacillus species for industrial production. Can. J. Microbial., 5o:1-17.

Shanmugaiah, V., Mathivanan N, Balasubramanian, N Manoharan PT.2008. Optimization of cultural conditions for production of chitinase by Bacillus laterosporous MML 2270 isolated from rice rhizosphere soil. Afr. J. Biotechnology, 7(15): 2562-68.

Sid Ahmed, A., C. P'erez, M. Ezziyyani and M.E.Candela, 2003. Effect of chitin on biological control activity of Bacillus spp. and Trichoderma harzianum against root rot disease in pepper (Capsicum annuum) plants. Euro. J. Plant Pathol, 109: 633-637.

Zhang, M., Haga A, Sekigchi H, Hirano S.2000. Structure of insect chitin isolated from beetle larva cuticle and silkworm (Bombyx mori) pupa exuvia. Int J Biol Macromol, 27: 99105.

Zhang, Z., Yuen GY, Sarath G, Penheiter AR.2001. Chitinases from the plant disease biocontrol agent Stenotrophomonas maltophilia C3. Phytopatology, 91: 204-211.

\section{How to cite this article:}

Abhilipsa Parhi and Sukantibala Mohapatra. 2017. Screening and Characterization of Rhizospheric Chitinolytic Bacteria for Evaluation of Their Potential as Biocontrol Agent against Phytopathogenic Fungi. Int.J.Curr.Microbiol.App.Sci. 6(9): 3457-3463.

doi: https://doi.org/10.20546/ijcmas.2017.609.424 